\title{
Plasmodium falciparum cytoadherence to ICAM-1 is associated with cerebral malaria
}

\author{
Lucy B Ochola ${ }^{1}$, Bethsheba R Siddondo ${ }^{1}$, Harold Ocholla ${ }^{1}$, Siana Nyka ${ }^{3}$, Eva N Kimani ${ }^{1}$, Thomas N Williams ${ }^{1}$, \\ Johnstone O Makale ${ }^{1}$, Anne Liljander ${ }^{4}$, Britta C Urban ${ }^{1,2}$, Pete Bull' ${ }^{1}$, Tadge Szestak ${ }^{2}$, Kevin Marsh', Alister G Craig ${ }^{2 *}$ \\ From Parasite to Prevention: Advances in the understanding of malaria \\ Edinburgh, UK. 20-22 October 2010
}

The pathology of sever malaria is in part related to the pro-inflammatory nature of the host response but a number of other factors are also thought to be involved, including the interaction between infected erythrocytes and endothelium. This phenotype involves a range of host receptors and the parasite-derived variant antigen PfEMP1, which is expressed on the surface of the infected erythrocyte membrane. Previous studies have suggested a role for ICAM-1 in the pathology of cerebral malaria, although these were inconclusive. In this study we measured the binding to CD36 and ICAM-1 of patient isolates from varying clinical syndromes under static and flow conditions. We also used mutant ICAM-1 proteins to characterise the key contact residues on ICAM-1 and produce a detailed binding phenotype. Our results show that increased binding to CD36 is associated with uncomplicated malaria while ICAM-1 adhesion under flow conditions is raised in parasites from cerebral malaria cases. The pattern of ICAM-1 binding has also been investigated using mutant ICAM1 proteins and indicates that isolates from severe malaria are biased towards a binding signature also seen with ITO4, a laboratory isolate selected for binding on human endothelium with similar receptor expression to that seen in the brain.

\footnotetext{
Author details

'KEMRI/Wellcome Trust Research Programme, P. O. Box 230, 80108 Kilifi, Kenya. ${ }^{2}$ Liverpool School of Tropical Medicine, Pembroke Place, Liverpool L3 5QA, UK. ${ }^{3}$ Dar es Salaam University College of Education, Faculty of Science, P.O. Box 2329, Dares Salaam, Tanzania. ${ }^{4}$ Department of Medicine Solna, Karolinska Institutet, Stockholm, Sweden.
}

Published: 20 October 2010

\footnotetext{
2Liverpool School of Tropical Medicine, Pembroke Place, Liverpool L3 5QA, UK
}

Full list of author information is available at the end of the article
doi:10.1186/1475-2875-9-S2-P27

Cite this article as: Ochola et al:: Plasmodium falciparum cytoadherence to ICAM-1 is associated with cerebral malaria. Malaria Journal 20109 (Suppl 2):P27.

\section{Submit your next manuscript to BioMed Central and take full advantage of: \\ - Convenient online submission \\ - Thorough peer review \\ - No space constraints or color figure charges \\ - Immediate publication on acceptance \\ - Inclusion in PubMed, CAS, Scopus and Google Scholar \\ - Research which is freely available for redistribution \\ Submit your manuscript at www.biomedcentral.com/submit}

C Biomed Central

C 2010 Craig et al; licensee BioMed Central Ltd. This is an open access article distributed under the terms of the Creative Commons Attribution License (http://creativecommons.org/licenses/by/2.0), which permits unrestricted use, distribution, and reproduction in any medium, provided the original work is properly cited. 